
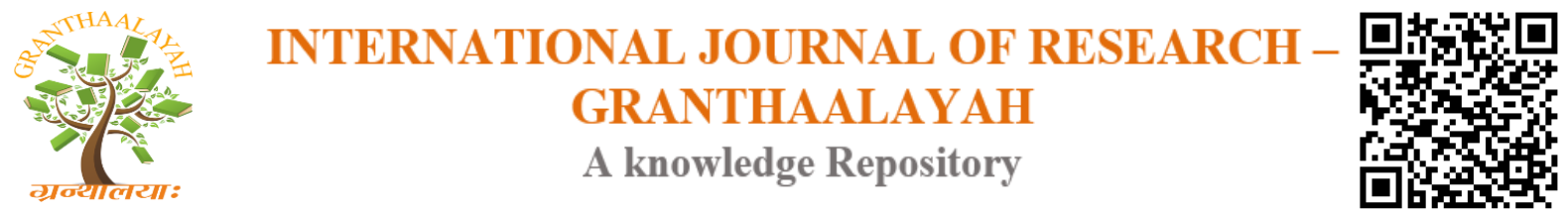

Social

\title{
CONSTRUCTING AND VALIDATING A SCALE FOR ASSESSING THE SOCIABILITY OF TEACHERS
}

\author{
Dr. C. Sherine Vinoca Snehalatha ${ }^{* 1}$ \\ ${ }^{* 1}$ Assistant Professor in English, Meston College of Education, Chennai.14, INDIA
}

DOI: https://doi.org/10.29121/granthaalayah.v4.i8(SE).2016.2586

\begin{abstract}
In the present context, educationist and education planners have started preferring social learning environments in the classrooms. Thus arises the need for teacher behaviour characteristically 'sociable' in nature. The ability to be in the company of others is the core of 'sociability'. On analyzing literature, the author has identified three constructs forming the core of sociability - Trust and belonging; Sense of community; and Good working relationship. On the basis of these altogether 36 statements were formed to be answered on a 4 point scale ranging from Strongly Agree to Strongly Disagree. After establishing content validity, item validity, and construct validity, the draft tool retained thirty items. The presence of the trait constructs were established by confirmatory factor analysis. The rested reliability coefficient 0.697 upholds the consistency of the tool.
\end{abstract}

Keywords:

Education, Learning Process, sociability, \& Working relationship.

Cite This Article: Dr. C. Sherine Vinoca Snehalatha, "CONSTRUCTING AND VALIDATING A SCALE FOR ASSESSING THE SOCIABILITY OF TEACHERS", International Journal of Research - Granthaalayah, Vol. 4, No. 8: SE (2016): 45-55.

\section{INTRODUCTION}

Teachers irrespective of the stages at which they are teaching or the cadre they hold, they have to play similar roles in the teaching - learning process. However, if someone starts listing the roles they play in different contexts, it keep on extending along with changes coming upon different phases of education, affecting the intellectual, emotional, social, moral, spiritual, and physical domains of the learners. Focusing on physical strength and health oriented education, the aims of education have been shifting from one to another with the passage of time on the basis of the philosophy of life the people hold and the scientific advancement opening spaces for adoption of quite different life styles. 
In the present educational scenario, the educationist and the educational planners, having realized the strength and weakness of IT / digital based teaching and learning, have started preferring social learning environment in the classrooms for securing social learning for learners. Thus arises the need for teacher behaviour characteristically sociable in nature for structuring an environment for promoting sociability among the students.

\section{BACKGROUND}

Sociability is a personality trait, the ability to be fond of the company of others; people who are sociable are inclined to seek out the opportunity of social contact with others (retrieved).

When one analyses the social nature of children it may be observed that the children acquire knowledge by interaction with others in their innate capacity. One can also recognize their enjoyment of being together - chatting, joking, laughing, working, and creating friendships. It is through this interaction they are initiated into new thoughts and feelings that help them approach different life situations. This is what being termed as 'sociability'.

The key aspects of sociability are those skills that help one understand and express feelings, and behaviours that facilitate positive relationships. It includes self-regulation, active listening, cooperation, and effective communication. All these work together to build social - emotional learning skills necessary for human thriving. That is why; Cathy Yeulet (2015) has marked sociability as the core of social - emotional learning (retrieved).

It has been shown that cooperative ability to engage with others is critical to successful learning communities. A study on the Economic Value of social - emotional learning suggests that classroom efforts to improve sociability are well worth the costs. The social - emotional learning programmes were found to have measurable benefits in the form of Reduced Aggression, and Improved impulse Control from 3 to 13 times more than their costs of schools. Sociability flourishes when individuals feel connected, respected, cared about and when they can communicate their feelings of connectivity with others. Besides education, sociability is also an advantage to business leaders for leading, managing, and innovating in a world of increasing complexity.

Therefore, sociability is increased when individuals cooperate with each other. In a place where cooperation is undervalued, and the individuals cooperate for power, status, or achievement, sociability is lost. It means that there is urgent need to shift from more traditional leadership approaches that force cooperation through rules, to ways of creating shared norms. In this setting in classrooms, teachers become facilitators as students discuss ways they would feel most supported, including how they should treat each other, what it means to respect different opinions, and ways of learning and what happens when they disagree. As a result of their involvement, student comes to own their belief that cooperation is the right way to behave. It is also an experiential lesson to understand sociability as the goal of democracy. 


\section{REVIEW}

In a study entitled 'the role of Sociability Self-concept in the relationship between exposure to and concern about aggression in middle schools', Miller Janic Williams (2013) has reported students who witnessed more aggression at schools tended to be more concerned about aggressive incidents occurring. The prediction of concern by exposure was stronger among students low in sociability self-concept and weaker for those high sociability self-concept. Sociability self-concept thus appeared to be protective factor in the sense that it buffered the effect of exposure to aggression on concern about violence at school.

Abedin Babik et al (2012) have identified in their study 'do non task interactions matter'? the relationship between non task sociability of computer supported collaborative learning and learning outcomes; five attributes opearationalising the non-task sociability: Finding help, Sense of appealing, Sense of boringness, Sense of interactivity, and Sense of frustration. By working on non-task sociability in the study entitled 'enhancing non task sociability of Asynchronous CSCL environments' Abedin Babik et al (2011) have developed and validated an instrument to measure social functionality of the environment.

The influence of family size and parenting style was investigated by Trent Katherine and Spitze Glenna (2011) in the study entitled 'growing up without siblings and adult sociability behaviors' and have reported that there are some differences in adult sociability behaviours between those who grew up with and without siblings. The study also suggests that these differences are not large or pervasive across a range of sociability behaviors and may grow smaller with age.

$\mathrm{Ng}$, Rowena et al (2013) have identified the link between emotional expressivity through music and sensitivity and responsibility to emotions of others in the case of people with Williams syndrome. Kreijans Karel et al (2007) in their study 'measuring perceived sociability of computer supported collaborative learning environments' have defined sociability 'as the extent to which an environment is perceived to be able to facilitate the emergence of a sound social space with attributes as Trust and Belonging, a strong sense of community, and Good Working Relationships. Specific environmental characteristics designated as 'social affordances' are stated to be the factors determining sociability. Further, the study deals with the construction and validation of a self-reporting sociability scale consisting of 10 items and has the internal consistence of 0.92 .

\section{PREPARATION OF THE DRAFT TOOL}

After reviewing the literature on sociability the researcher has understood that this area is not yet much investigated to identify the positive impact of the trait sociability on different personality characteristics and its advantages of application in the field of education and other allied fields. Though sociability has been studied in different context in the field of education pertaining to students, classrooms, teachers, and other institutional environments; still there are possibilities for in-depth studies on sociability in terms of teachers of different cadres, institutions of different categories, institutions offering academic, vocational, and other professional courses. The studies reviewed are mostly children oriented or individuals of typical development. 
Since sociability has been established as a crucial factor for fostering essential social skills in individuals to be persons of social wellbeing, in the school context the teachers are expected to be sources for creating a social environment for teaching learning process so as to inculcate the same in the learners. That is, unless the teachers are sociable, sociability cannot be practiced in the classrooms. The adoption of group method, collaborative learning method, etc for the maintenance of relationships among the members of the groups is of very importance for the successful practice of cooperation, coordination, and collaboration leading to sociability. In the study reported by Kreijans Karel et al (2007), it is shown that the sociability exists in a school environment when the members feel the presence of trust and belonging; sense of community; and good working relationships. These are to be understood as the constructs of sociability in an academic environment. Such an environment will become feasible only when the teachers practice all these three attributes of sociability in the school environment. Therefore, the researcher has treated trust and belonging, sense of community and good working relationship as the dimensions of sociability existing in classroom environment.

On the basis of this, statements have been prepared to be included under each dimension to be answered by the subjects in a four point scale as:

Strongly Agree - Agree Disagree - Strongly Disagree.

The following table furnishes the number of statements prepared for the proposed sociability scale.

Table 1: Dimension wise number of statements of the Sociability Scale

\begin{tabular}{|l|l|l|}
\hline S.No & Dimension & No. of Items \\
\hline 1 & Trust and Belonging & 12 \\
\hline 2 & Sense of Community & 12 \\
\hline 3 & Good Working Relationship & 12 \\
\hline Total & 36 \\
\hline
\end{tabular}

\section{VALIDATION OF THE TOOL}

Validity of an assessment is the degree to which it measures what it is supposed to measure. Validity is also dependent on the instrument measuring what it was designed to measure, and not something else instead. Validity is based on matters of degrees; validity is not an all or nothing idea.

\section{CONTENT VALIDITY}

Copies of the Draft Tool were provided to Three Experts guiding Doctoral studies in Education with a request to study the appropriateness of the statements prepared and offer suggestions for better alterations or modifications. On the basis of the suggestions provided by the experts alterations and verbal reforms were made to make the tool more relevant and appropriate to assess the sociability. 


\section{ITEM VALIDITY}

To establish the statistical validity, the modified Draft tool was administered to 100 higher secondary students. After scoring responses of the respondents, the validity of each item has been established by subjecting the data to Goodness of Fit Test, which is otherwise called one sample test of chi square. It is one of the several applications of chi square test (Cohen Louis, 1976).Here it is used to test the null hypothesis formed for every Reaction statement in the draft tool that the responses obtained under Strongly Agree, Agree, Disagree, and Strongly Disagree are not by CHOICE.

Table 2 furnishes the Goodness of Fit value for all the 36 items prepared.

Table 2: Goodness of Fit Value of Items of Sociability Scale

\begin{tabular}{|l|l|l|l|l|l|l|l|}
\hline $\begin{array}{l}\text { Item } \\
\text { No. }\end{array}$ & $\begin{array}{l}\text { Goodness } \\
\text { of Fit } \\
\text { Value }\end{array}$ & $\begin{array}{l}\text { Table } \\
\text { Value at } \\
\text {.01Level }\end{array}$ & $\begin{array}{l}\text { Remark } \\
\text { on } \mathbf{H}_{\mathbf{0}}\end{array}$ & $\begin{array}{l}\text { Item } \\
\text { No. }\end{array}$ & $\begin{array}{l}\text { Goodness } \\
\text { of Fit } \\
\text { Value }\end{array}$ & $\begin{array}{l}\text { Table } \\
\text { Value at } \\
\text {.01Level }\end{array}$ & $\begin{array}{l}\text { Remark } \\
\text { on } \mathbf{H}_{\mathbf{0}}\end{array}$ \\
\hline 1 & 26.18 & 11.34 & Rejected & 19 & 35.76 & 11.34 & Rejected \\
\hline 2 & 48.62 & 11.34 & Rejected & 20 & 41.76 & 11.34 & Rejected \\
\hline 3 & 32.15 & 11.34 & Rejected & 21 & 32.71 & 11.34 & Rejected \\
\hline 4 & 30.48 & 11.34 & Rejected & 22 & 8.92 & 11.34 & Accepted \\
\hline 5 & 28.62 & 11.34 & Rejected & 23 & 31.76 & 11.34 & Rejected \\
\hline 6 & 26.95 & 11.34 & Rejected & 24 & 31.20 & 11.34 & Rejected \\
\hline 7 & 28.48 & 11.34 & Rejected & 25 & 30.96 & 11.34 & Rejected \\
\hline 8 & 7.29 & 11.34 & Accepted & 26 & 29.07 & 11.34 & Rejected \\
\hline 9 & 35.48 & 11.34 & Rejected & 27 & 19.62 & 11.34 & Rejected \\
\hline 10 & 34.42 & 11.34 & Rejected & 28 & 29.52 & 11.34 & Rejected \\
\hline 11 & 29.64 & 11.34 & Rejected & 29 & 33.67 & 11.34 & Rejected \\
\hline 12 & 23.41 & 11.34 & Rejected & 30 & 29.34 & 11.34 & Rejected \\
\hline 13 & 33.36 & 11.34 & Rejected & 31 & 26.82 & 11.34 & Rejected \\
\hline 14 & 31.52 & 11.34 & Rejected & 32 & 25.68 & 11.34 & Rejected \\
\hline 15 & 61.28 & 11.34 & Rejected & 33 & 38.80 & 11.34 & Rejected \\
\hline 16 & 8.61 & 11.34 & Accepted & 34 & 45.08 & 11.34 & Rejected \\
\hline 17 & 34.24 & 11.34 & Rejected & 35 & 26.64 & 11.34 & Rejected \\
\hline 18 & 34.21 & 11.34 & Rejected & 36 & 22.16 & 11.34 & Rejected \\
\hline
\end{tabular}

Table 2 shows that 33 Statements are Retained because the stated null hypotheses for these statements are Rejected at 0.01 level.

\section{CONSTRUCT VALIDITY}

Using the tabulated data, the Item - Dimension total correlation was computed for each Statement to establish the construct validity of the newly formed tool. The Dimensions:Trust 
and Belonging, Sense of Community, and Good Working Relationship are incorporated in the Statements.

Table 3 reveals the Item - Dimension total correlation for the 33 items.

Table 3: Item - Dimension Total Correlation value of Sociability Scale

\begin{tabular}{|l|l|l|l|l|l|}
\hline Item No & r Value & Item No & r Value & Item No & r Value \\
\hline 1 & 0.48 & 12 & 0.34 & 23 & 0.46 \\
\hline 2 & 0.51 & 13 & 0.62 & 24 & 0.38 \\
\hline 3 & $0.04^{*}$ & 14 & 0.51 & 25 & 0.52 \\
\hline 4 & 0.43 & 15 & 0.59 & 26 & 0.23 \\
\hline 5 & 0.26 & 16 & 0.38 & 27 & 0.24 \\
\hline 6 & 0.54 & 17 & 0.40 & 28 & 0.29 \\
\hline 7 & 0.39 & 18 & 0.27 & 29 & $0.10^{*}$ \\
\hline 8 & 0.32 & 19 & 0.39 & 30 & 0.61 \\
\hline 9 & $0.09 *$ & 20 & 0.50 & 31 & 0.35 \\
\hline 10 & 0.21 & 21 & 0.46 & 32 & 0.29 \\
\hline 11 & 0.28 & 22 & 0.28 & 33 & 0.21 \\
\hline
\end{tabular}

\section{* items deleted}

From table 3 it may be seen that 30 Statements are significantly correlated with their respective dimensions and retained in the scale; whereas three statements which have not secured significant correlation with their dimension were deleted.

Thereafter, correlation was computed between the dimension wise total and the overall total of the scale. The noted correlation coefficients are provided in table 4.

Table 4: Dimension - Total Correlation of Sociability Scale

\begin{tabular}{|l|l|l|l|}
\hline S.N & Dimension & 'r' value & Significance \\
\hline 1 & Trust and belonging & 0.69 & 0.00 \\
\hline 2 & Sense of community & 0.81 & 0.00 \\
\hline 3 & Good working relationship & 0.76 & 0.00 \\
\hline
\end{tabular}

Since the correlation between dimensions and overall total score of Sociability Scale is significant at $1 \%$ level, the contribution of dimensions to the total score is confirmed.

\section{FACTORIAL VALIDITY}

Finally the researcher has decided to make the process of validation complete by Factor Analysis. The partially validated draft tool was again administered to 200 subjects chosen by random from various schools of Tirunelveli district. The tabulated data were used for Factor Analysis. 
The process of factor analysis started with the extraction of Communality Values for all the 30 items. The Extracted Values are furnished in Table 5. All the 30 items have recorded more than 0.61 , proving their suitability for inclusion.

Table 5: Communality value of Sociability Scale

\begin{tabular}{|l|l|l|l|l|l|l|l|l|}
\hline $\begin{array}{l}\text { Item } \\
\text { No }\end{array}$ & $\begin{array}{l}\text { Initial } \\
\text { value }\end{array}$ & Extraction & $\begin{array}{l}\text { Item } \\
\text { No }\end{array}$ & $\begin{array}{l}\text { Initial } \\
\text { value }\end{array}$ & Extraction & $\begin{array}{l}\text { Item } \\
\text { No }\end{array}$ & $\begin{array}{l}\text { Initial } \\
\text { value }\end{array}$ & Extraction \\
\hline 1 & 1.00 & 0.62 & 2 & 1.00 & 0.70 & 3 & 1.00 & 0.72 \\
\hline 4 & 1.00 & 0.74 & 5 & 1.00 & 0.71 & 6 & 1.00 & 0.66 \\
\hline 7 & 1.00 & 0.63 & 8 & 1.00 & 0.82 & 9 & 1.00 & 0.81 \\
\hline 10 & 1.00 & 0.82 & 11 & 1.00 & 0.76 & 12 & 1.00 & 0.66 \\
\hline 13 & 1.00 & 0.69 & 14 & 1.00 & 0.66 & 15 & 1.00 & 0.69 \\
\hline 16 & 1.00 & 0.64 & 17 & 1.00 & 0.78 & 18 & 1.00 & 0.82 \\
\hline 19 & 1.00 & 0.65 & 20 & 1.00 & 0.72 & 21 & 1.00 & 0.61 \\
\hline 22 & 1.00 & 0.62 & 23 & 1.00 & 0.64 & 24 & 1.00 & 0.82 \\
\hline 25 & 1.00 & 0.70 & 26 & 1.00 & 0.68 & 27 & 1.00 & 0.79 \\
\hline 28 & 1.00 & 0.64 & 29 & 1.00 & 0.72 & 30 & 1.00 & 0.81 \\
\hline
\end{tabular}

The further analysis to explain the total variance of each component by Initial Eigen Values is given in Table 6.

Table 6: Extraction Sums of Squared Loading of Sociability Scale

Total Variance Explained

\begin{tabular}{|l|l|l|l|l|l|l|}
\hline \multirow{2}{*}{ Component } & Initial Eigen values & \multicolumn{3}{l|}{ Extraction Sums of Squared Loadings } \\
\cline { 2 - 7 } & Total & $\%$ of Variance & Cumulative \% & Total & $\%$ of Variance & Cumulative \% \\
\hline 1 & 7.167 & 23.886 & 23.886 & 7.167 & 23.886 & 23.886 \\
2 & 5.324 & 17.741 & 41.627 & 5.324 & 17.741 & 41.627 \\
3 & 4.326 & 14.422 & 56.049 & 4.326 & 14.422 & 56.049 \\
4 & 3.658 & 12.190 & 68.239 & 3.658 & 12.190 & 68.239 \\
5 & 2.854 & 9.513 & 77.752 & 2.854 & 9.513 & 77.752 \\
6 & 1.452 & 4.815 & 82.567 & 1.452 & 4.815 & 82.567 \\
7 & 1.124 & 3.742 & 86.309 & 1.124 & 3.742 & 86.309 \\
8 & 965 & 3.213 & 89.522 & .965 & 3.213 & 89.522 \\
9 & .854 & 2.843 & 92.365 & .854 & 2.843 & 92.365 \\
10 & 851 & 2.833 & 95.150 & .851 & 2.833 & 95.150 \\
11 & .710 & 2.791 & 97.989 & .710 & 2.791 & 97.989 \\
12 & .617 & 2.054 & 100.000 & .617 & 2.054 & 100.000 \\
13 & $5.632 \mathrm{E}-16$ & $1.083 \mathrm{E}-15$ & 100.000 & & & \\
14 & $5.065 \mathrm{E}-16$ & $9.740 \mathrm{E}-16$ & 100.000 & & & \\
15 & $2.619 \mathrm{E}-16$ & $5.037 \mathrm{E}-16$ & 100.000 & & & \\
16 & $2.166 \mathrm{E}-16$ & $4.165 \mathrm{E}-16$ & 100.000 & & & \\
17 & $1.437 \mathrm{E}-16$ & $2.764 \mathrm{E}-16$ & 100.000 & & & \\
18 & $9.785 \mathrm{E}-17$ & $1.882 \mathrm{E}-16$ & 100.000 & & & \\
19 & $7.925 \mathrm{E}-17$ & $1.524 \mathrm{E}-16$ & 100.000 & & & \\
20 & $-4.323 \mathrm{E}-17$ & $-8.313 \mathrm{E}-17$ & 100.000 & & & \\
\end{tabular}




\begin{tabular}{|l|l|l|l|l|l|l|}
21 & $-1.489 \mathrm{E}-16$ & $-2.863 \mathrm{E}-16$ & 100.000 & & & \\
22 & $-2.430 \mathrm{E}-16$ & $-4.673 \mathrm{E}-16$ & 100.000 & & \\
23 & $-2.960 \mathrm{E}-16$ & $-5.692 \mathrm{E}-16$ & 100.000 & & \\
24 & $-4.185 \mathrm{E}-16$ & $-8.048 \mathrm{E}-16$ & 100.000 & & \\
25 & $5.632 \mathrm{E}-16$ & $1.083 \mathrm{E}-15$ & 100.000 & & \\
26 & $5.065 \mathrm{E}-16$ & $9.740 \mathrm{E}-16$ & 100.000 & & \\
27 & $2.619 \mathrm{E}-16$ & $5.037 \mathrm{E}-16$ & 100.000 & & \\
28 & $-7.980 \mathrm{E}-17$ & $-2.955 \mathrm{E}-16$ & 100.000 & & \\
29 & $-2.495 \mathrm{E}-16$ & $-9.241 \mathrm{E}-16$ & 100.000 & & & \\
30 & $-4.100 \mathrm{E}-16$ & $-1.518 \mathrm{E}-15$ & 100.000 & & & \\
\hline
\end{tabular}

It is understood from the table that the first three components explain a variance ranging from 23.866 to 56.049., while the components four, five and six are shown to explain the variance to the maximum of $68.239,77.752$, and 82.567 respectively. It may be understood that though three components have been incorporated in the scale, another three components of lesser values seem to be present. Therefore, considering the negligible difference between the components three and four; and four and five; and five and six, all the three have been (4,5,and 6) have been dropped. Therefore, these three components may be treated as the major constructs of the instrument designed to assess sociability.

Thereafter, the contribution of each item to these three factors has been computed principal component analysis using Varimax Rotation Method with Kaiser normalization. The generated rotated component matrix is given in Table 7.

Table 7: Principal Component Analysis values of Sociability Scale

\begin{tabular}{|l|l|l|l|l|l|l|}
\hline \multirow{2}{*}{ Component } & \multicolumn{7}{|l|}{} \\
\cline { 2 - 7 } & $\mathbf{1}$ & $\mathbf{2}$ & $\mathbf{3}$ & $\mathbf{4}$ & $\mathbf{5}$ & $\mathbf{6}$ \\
\hline item1 & .487 & .462 & -.263 & .482 & .298 & -.224 \\
\hline item2 & -.182 & .383 & .518 & .255 & .194 & .103 \\
\hline item3 & .250 & -.101 & .302 & -.193 & -.096 & .422 \\
\hline item4 & .250 & .048 & -.317 & -.285 & .300 & .068 \\
\hline item5 & .174 & .256 & .235 & .037 & .196 & -.068 \\
\hline item6 & -.397 & -.064 & .443 & .233 & .379 & .110 \\
\hline item7 & .328 & .244 & .196 & .146 & -.019 & .532 \\
\hline item8 & -.138 & .357 & -.017 & -.041 & -.428 & -.257 \\
\hline item9 & .163 & -.184 & .368 & -.418 & -.490 & .365 \\
\hline item10 & .236 & -.174 & .417 & .413 & .219 & -.027 \\
\hline item11 & .144 & .235 & -.036 & .155 & .010 & .230 \\
\hline item12 & .373 & -.104 & .007 & .238 & -.281 & -.368 \\
\hline item13 & .343 & -.022 & -.123 & -.079 & .124 & .048 \\
\hline item14 & .164 & .231 & .019 & -.386 & -.130 & .090 \\
\hline item15 & -.009 & .152 & .438 & -.193 & -.098 & -.241 \\
\hline item16 & .270 & .110 & .228 & .102 & -.054 & .089 \\
\hline item17 & .166 & .303 & .026 & .285 & -.053 & .289 \\
\hline item18 & .045 & .472 & .396 & -.008 & .479 & -.357 \\
\hline item19 & -.571 & .203 & .312 & -.324 & -.246 & .212 \\
\hline
\end{tabular}




\begin{tabular}{|l|l|l|l|l|l|l|}
\hline item20 & -.037 & .340 & -.344 & .258 & .238 & -.229 \\
\hline item21 & .444 & .047 & .284 & -.169 & .281 & .058 \\
\hline item22 & .313 & .040 & -.054 & -.101 & -.222 & -.090 \\
\hline item23 & .277 & .281 & -.268 & -.082 & -.388 & -.089 \\
\hline item24 & .282 & -.141 & .373 & .357 & .181 & .107 \\
\hline item25 & .464 & .325 & -.166 & -.029 & -.010 & -.058 \\
\hline item26 & .059 & .342 & -.281 & -.568 & .144 & .450 \\
\hline item27 & -.297 & .477 & .350 & .137 & -.282 & .361 \\
\hline item28 & -.157 & .176 & .301 & .288 & .522 & -.189 \\
\hline item29 & -.419 & .341 & .059 & .302 & .168 & .617 \\
\hline item30 & .325 & -.078 & .207 & -.218 & .076 & .162 \\
\hline
\end{tabular}

It reveals in table 7 that each item has obtained higher loadings on the component for which it has been structured, confirming the validity of each item incorporated in the tool.

\section{RELIABILITY}

The reliability coefficient of the tool has been established by test and retest method. The computed reliability coefficient $\mathbf{0 . 6 9 7}$ shows that the tool is highly reliable.

\section{Final form and Dimension wise Item Categorization}

The items meant for different dimensions of the final tool are furnished in table 8 .

Table 8: Items of the Sociability Scale - Dimension wise

\begin{tabular}{|l|l|}
\hline Dimensions & Statements \\
\hline Trust and belonging & $1,4,7,12,13,16,21,22,25,30$ \\
\hline Sense of community & $2,5,8,11,14,17,20,23,26,29$ \\
\hline Good working relationship & $3,6,9,10,15,18,19,24,27,28$ \\
\hline
\end{tabular}

\section{SCORING}

All the thirty items are positive in nature. Therefore, the scoring of each item is to be followed as four for strongly agree, three for agree, two for disagree, and one for strongly disagree.

\section{FINAL FORM OF THE TOOL}

Kindly go through each one of the thirty statements given carefully and give your response under any one of the four responses strongly agree, agree, disagree, and strongly disagree by putting a tick mark $(\sqrt{ })$. Kindly answer all the statements without fail.

\begin{tabular}{|l|l|l|l|l|}
\hline S.N & Statement & & & \\
\hline 1 & All those serving with me in the institution are trustworthy. & & & \\
\hline 2 & Our institution functions asa social community. & & & \\
\hline 3 & No one of my colleagues will come to the institution late. & & & \\
\hline
\end{tabular}




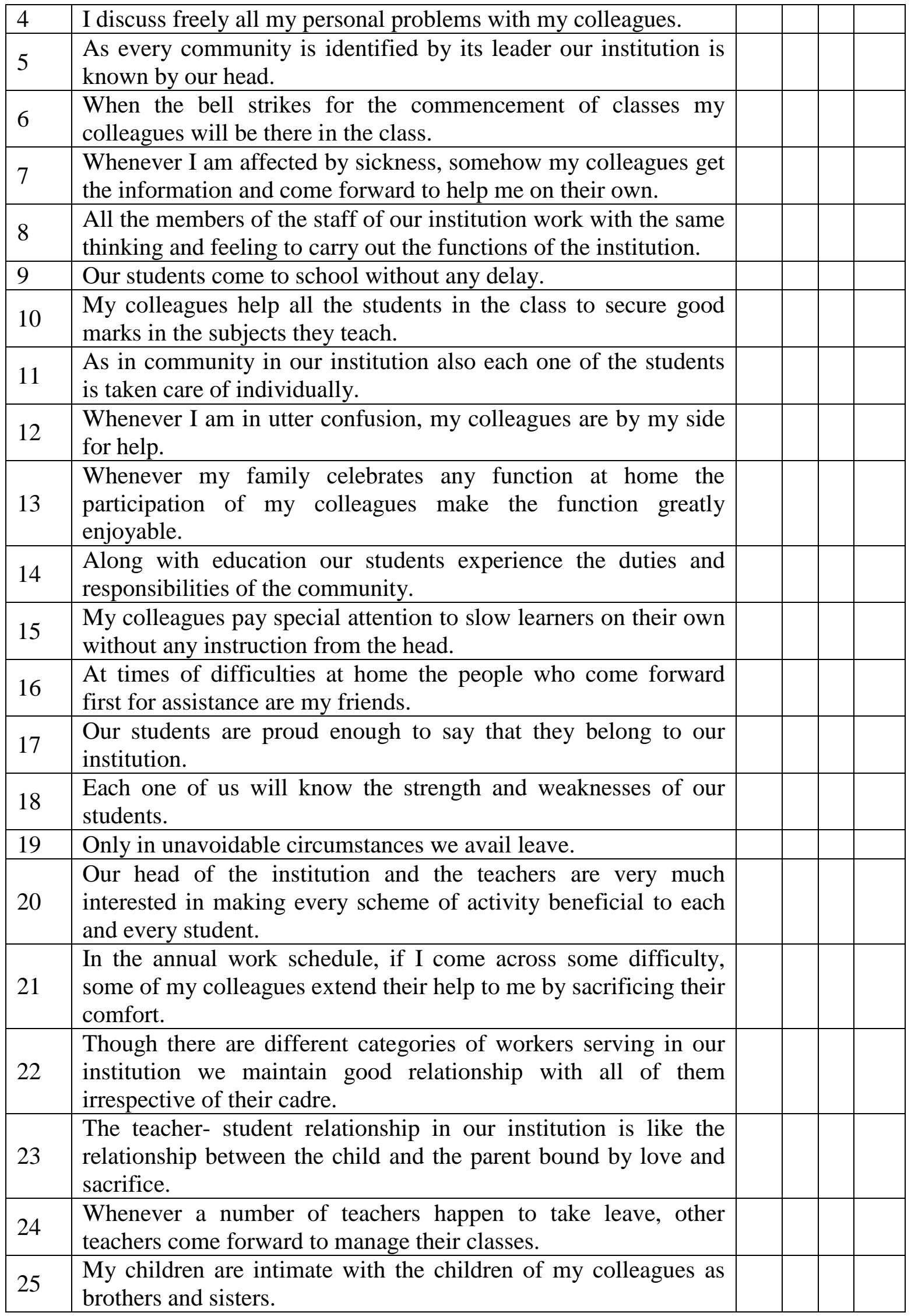




\begin{tabular}{|l|l|l|l|l|}
\hline 26 & $\begin{array}{l}\text { Students who violate the norms of the institution are inducted in } \\
\text { suitable programmes for correcting their behaviour. }\end{array}$ & & & \\
\hline 27 & $\begin{array}{l}\text { The head of the institution makes all efforts to help teachers get } \\
\text { the benefits due for them from the Government or from the } \\
\text { management. }\end{array}$ & $\begin{array}{l}\text { Our institution functions smoothly without any disturbances from } \\
\text { the side of the students or from teachers. }\end{array}$ & & \\
\hline 29 & $\begin{array}{l}\text { Our students get amble training for developing values necessary } \\
\text { for serving the community for its welfare and development. }\end{array}$ & $\begin{array}{l}\text { Our institution helps us to build up trust and relationship among } \\
\text { ourselves. }\end{array}$ & & \\
\hline 30 &
\end{tabular}

\section{REFERENCES}

[1] Abedin Babik et al (2011), Enhancing Non-Task Sociability of Asynchronous CSCL Environments, Computers \& Education, v57 n4 p2535-2547 Dec 2011.

[2] Abedin Babik et al (2012), Do Nontask Interactions Matter? The Relationship between Nontask Sociability of Computer Supported Collaborative Learning and Learning Outcomes, British Journal of Educational Technology, v43 n3 p385-397 May 2012.

[3] Cathy Yeulet (2015), Sociability: The Core of Social-Emotional Learning: How we foster kids' cooperative ability to interact with others, retrieved from <https://www.psychologytoday. com/blog/the-moment-youth/201505/sociability-the-coresocial-emotional-learning>

[4] Golden, S. A. R. (2011). Strategy For Success Of Human Beings:-Time Management.

[5] Golden, S. A. R. (2011). Problems and Prospectus of Distance Learning. Bharathidhasan University, 343, 344.

[6] Kreijans Karel et al (2007), Measuring Perceived Sociability of Computer-Supported Collaborative Learning Environments, Computers \& Education, v49 n2 p176-192 Sep 2007.

[7] Miller Janic Williams (2013), The Role of Sociability Self-Concept in the Relationship between Exposure to and Concern about Aggression in Middle School, RMLE Online: Research in Middle Level Education, v36 n7 2013.

[8] Regi, S. B., \& Golden, S. A. R. (2014). A Study On Educational Loan Availed By Students In Trichy City. JOURNAL OF INTERNATIONAL ACADEMIC RESEARCH FOR MULTIDISCIPLINARY (JIARM), 2(1).

[9] Ng, Rowena et al (2013), Musicality Correlates with Sociability and Emotionality in Williams Syndrome, Journal of Mental Health Research in Intellectual Disabilities, v6 n4 p268-279 2013.

[10] Trent Katherine and Spitze Glenna (2011), Growing Up without Siblings and Adult Sociability Behaviors, Journal of Family Issues, v32 n9 p1178-1204 Sep 2011. 